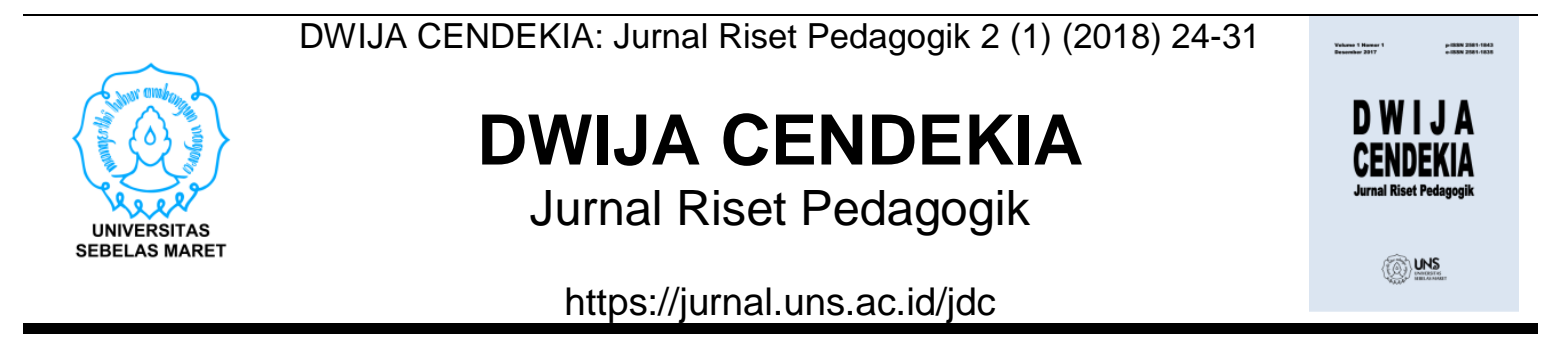

\title{
KELAYAKAN ISI BUKU TEKS BAHASA INDONESIA KELAS X EDISI REVISI 2016 DITINJAU DARI IMPLIKASI PENDEKATAN SAINTIFIK PADA KURIKULUM 2013 REVISI
}

\author{
Indah Sari, Fatehatun Nikmah, Titi Indah Rahayu, Santi Pratiwi Tri Utami \\ Universitas Negeri Semarang
}

\section{Sejarah Artikel}

Diterima 14 Juli 2018

Disetujui 20 Juli 2018

Diterbitkan 1 Agustus 2018

\section{Kata Kunci}

kurikulum, buku teks, kelayakan isi

\begin{abstract}
Abstrak
Penelitian ini di latar belakangi oleh adanya permasalahan dalam buku teks bahasa Indonesia kelas X SMA edisi revisi 2016. Permasalahan tersebut terdapat pada bagian kelengkapan materi, kedalaman materi, dan kesesuaian materi dengan kurikulum. Kualitas buku teks pelajaran yang dijadikan sumber pembelajaran turut menentukan hasil pencapaian tujuan pembelajaran. Pengabaian buku teks berarti mengabaikan mutu pembelajaran juga. Oleh karena itu diperlukan analisis untuk mengetahui kelayakan buku. Penelitian ini bertujuan untuk mendeskripsikan kelayakan isi buku teks bahasa Indonesia kelas $X$ edisi revisi 2016 ditinjau dari implikasi pendekatan saintifik pada kurikulum 2013 revisi sehingga dapat menjelaskan mengenai kelayakan isi buku tersebut. Pendekatan dalam penelitian ini adalah pendekatan kualitatif. Teknik pengumpulan data penelitian ini melalui angket (rubrik kelayakan isi), observasi, wawancara dan dokumentasi. Sumber data pada penelitian ini adalah buku teks bahasa Indonesia kelas X SMA edisi revisi 2016. Hasil penelitian menunjukkan bahwa buku teks bahasa Indonesia kelas X SMA edisi revisi 2016 ini layak dari aspek kelayakan isinya. Hal ini didukung dari nilai rata-rata per bab yakni 8,4 dari nilai sempurna 10. Meski demikian buku teks ini masih memiliki kekurangan terutama dibagian kelengkapan materi, dan kedalaman materinya.
\end{abstract}

\section{Cara Mengutip}

Indah, S., Nikmah, F., Rahayu, T.I., \& Utami, S.P.T. (2018). Kelayakan Isi Buku Teks Bahasa Indonesia Kelas X Edisi Revisi 2016 ditinjau dari Implikasi Pendekatan Saintifik ada Kurikulum 2013 Revisi. DWIJA CENDEKIA: Jurnal Riset Pedagogik, 2 (1), 24-31 


\section{PENDAHULUAN}

Dalam Undang-undang Nomor 20 Tahun 2003 tentang Sistem Pendidikan Nasional (Sisdiknas), disebutkan bahwa kurikulum merupakan seperangkat rencana atau pengaturan mengenai tujuan, isi, dan bahan pelajaran serta cara yang digunakan sebagai pedoman penyelenggaraan kegiatan pembelajaran untuk mencapai tujuan pendidikan. Kurikulum di Indonesia sudah beberapa kali mengalami perubahan, hal ini tentu disesuaikan dengan perkembangan dan tuntutan zaman. Kurikulum yang berlaku di Indonesia saat ini adalah kurikulum 2013 revisi.

Adanya perubahan kurikulum berbanding lurus dengan berbagai perubahan aspek pembelajaran pula, salah satunya perubahan buku teks yang digunakan. Buku teks merupakan elemen/unsur yang umum digunakan dalam pembelajaran (Mohammadi, 2014). Sebagai sumber belajar pokok, buku teks memiliki kedudukan yang penting dalam proses pembelajaran. Oleh karena itu, buku teks yang digunakan harus benar-benar diperhatikan kualitas kelayakannya. Buku teks atau buku pelajaran adalah buku yang berisi uraian bahan tentang mata pelajaran atau bidang tertentu, yang disusun secara sistematis dan telah diseleksi berdasarkan tujuan tertentu, orientasi pembelajaran dan perkembangan siswa untuk diasimilasikan. Buku ini dapat dipakai sebagai sarana belajar dalam kegiatan pembelajaran di sekolah (Agustina dalam Firdaus dkk, 2014:3).

Buku teks yang diterbitkan oleh Kemendikbud tentunya sudah sesuai dengan kurikulum yang berlaku dan mengalami proses yang ketat sebelum diterbitkan, akan tetapi tidak menutup kemungkinan masih ada kekurangan. Buku teks yang berkualitas menurut Badan Standar Nasional Pendidikan (BSNP) wajib memenuhi empat aspek yakni, aspek kelayakan bahasa, penyajian, grafika, dan isi.

Kelayakan isi menjadi aspek yang vital karena terkait ketercapaian esensi pembelajaran. Dalam hal kelayakan isi, ada lima indikator yang harus diperhatikan yaitu (1) kesesuaian uraian materi dengan standar kompetensi (SK) atau kompetensi inti (KI) dan kompetensi dasar (KD); (2) kelengkapan materi; (3) kedalaman materi; (4) keakuratan materi; dan (5) kesesuaian materi dengan perkembangan ilmu pengetahuan, fitur, dan rujukan (Hartono 2016:109).

Pengukuran kelayakan isi buku teks juga telah ditetapkan oleh Badan Standar Nasional Pendidikan (BSNP). Jika buku teks yang dianalisis berdasarkan komponen yang telah ditetapkan oleh BSNP dan ternyata masih terdapat banyak komponen yang belum sesuai maka buku teks tersebut dapat dikatakan belum memenuhi aspek kelayakan atau belum layak.

Buku teks kelas $X$ edisi revisi 2016 terbitan Kemendikbud secara umum sudah baik karena sebelum diterbitkan buku tersebut sudah melalui berbagai proses yang sangat ketat. Namun masih saja terdapat kekurangan yaitu ditemukan keluhankeluhan dari guru dan siswa terkait buku teks bahasa Indonesia kelas $X$ edisi revisi 2016. Hal yang dikritik adalah tentang kelengkapan materi dalam buku teks bahasa Indonesia kelas X edisi revisi 2016, ada satu materi yang tidak ada yakni terkait 
buku fiksi dan nonfiksi. Selain itu menurut siswa bahasa dalam buku teks bahasa Indonesia kelas $\mathrm{X}$ edisi revisi 2016 sukar dipahami sehingga membuat mereka bingung. Padahal pada edisi sebelumnya juga terdapat kritik yang hampir sama yakni tentang materi, namun pada terbitan edisi 2016 juga tidak terlalu banyak perubahan berdasarkan kritik yang yang dilakukan pada edisi sebelumnya.

Selain itu kritik yang lain untuk buku teks bahasa Indonesia kelas $X$ edisi revisi 2016 adalah, observasi yang dilakukan salah satu bab yakni bab ketiga. Dari hasil observasi tersebut, dapat disimpulkan bahwa 1) ditemukan ketidaksinambungan antara KD (kompetensi dasar) dengan rumusan indikator; 2) urutan indikator yang tidak sesuai atau tidak runtut (dari C1-C6); 3) penggunaan kata kerja operasional yang kurang tepat (tidak dapat diukur); 4) uraian materi belum sesuai dengan KD (kompetensi dasar); 5) isi dari uraian materi tidak sesuai dengan tujuan pembelajaran; dan 6) konsep serta teori yang disajikan tidak sesuai tujuan pencapaian KD (kompetensi dasar).

Penelitian tentang analisis buku teks memang sudah banyak di lakukan, diantaranya, Rahmawati (2014) yang meneliti buku teks Bahasa Indonesia Kelas X SMA/SMK Kurikulum 2013. Hendrawanto (2017) yang meneliti kelayakan buku teks (kebahasaan, isi, penyajian, kegrafikan dan keterbacaan). Selanjutnya ada penelitian yang lain mengenai analisis buku teks juga dilakukan di luar negeri. Wikman dan Horsley (2012) meneliti tentang buku teks yang digunakan di Australia dan Finlandia. Penelitian tersebut diterbitkan oleh jurnal International
Association for Research on Textbooks and Educational volume 5. Meskipun sudah banyak penelitian tentang kelayakan buku teks, namun penelitian-penelitian tersebut masih memiliki kendala. Sehingga perlu dilakukan penelitianpenelitian kembali dengan belajar dari pengalaman dari penelitian sebelumnya.

Berdasarkan beberapa temuan masalah dan data di lapangan tersebut, penelitian mengenai analisis buku teks sangat diperlukan. Analisis buku teks adalah salah satu cara untuk menguji kualitas sebuah buku, yaitu dengan menganalisis buku teks Bahasa Indonesia. Buku teks yang akan diteliti adalah buku teks bahasa Indonesia kelas X edisi revisi 2016. Buku tersebut digunakan dalam pembelajaran sehingga perlu diketahui kualitas kelayakannya, semakin baik kualitas buku teksnya maka akan semakin baik pula dalam menunjang pembelajaran.

Buku teks bahasa Indonesia yang bermutu tinggi akan meningkatkan kualitas dan hasil pembelajaran. Dengan demikian buku teks harus memenuhi standar yang telah ditetapkan. Standar yang dimaksud adalah karakteristik dan komponen minimum yang harus dimiliki sebuah buku. Menurut BSNP kualitas buku teks yang baik harus memenuhi empat aspek kelayakan, yaitu kelayakan isi, kelayakan penyajian, kelayakan kebahasaan, dan kelayakan kegrafikaan. Dan menurut Pusat Perbukuan Depdiknas menyebutkan tiga aspek standar kelayakan buku teks pelajaran bahasa Indonesia, yaitu aspek materi atau isi, aspek penyajian, dan aspek kebahasaan.

Berdasarkan uraian diatas, peneliti tertarik untuk menganalisis 
buku teks bahasa Indonesia kelas $X$ edisi revisi 2016 pada kurikulum 2013 revisi, khususnya pada aspek kelayakan isi, karena bagian isi sebuah buku merupakan hal yang paling utama (inti) dan mendasar.

\section{METODE PENELITIAN}

Penelitian ini menggunakan pendekatan kualitatif. Sumber data pada penelitian ini adalah buku teks Bahasa Indonesia kelas $X$ edisi revisi 2016. Sedangkan datanya adalah isi dari buku teks Bahasa Indonesia kelas X edisi revisi 2016. Buku teks bahasa Indonesia kelas $X$ edisi revisi 2016 merupakan buku terbitan dari Kemendikbud yang dijadikan buku pegangan pokok dalam pembelajaran, khususnya kurikulum 2013 revisi. Teknik pengumpulan data yang digunakan dalam penelitian ini adalah kuesioner (rubrik kelayakan isi), wawancara, observasi, dan dokumentasi. Metode yang digunakan untuk menganalisis adalah metode analisis isi, lalu untuk menjabarkan hasil penelitian adalah metode diskriptif kualitatif.

\section{PEMBAHASAN}

Buku teks pelajaran yang berkualitas wajib memenuhi empat unsur kelayakan. Empat unsur kelayakan buku teks tersebut yaitu, (1) isi atau materi pelajaran, (2) penyajian materi, (3) bahasa dan keterbacaan, dan (4) format buku atau grafika (Depdiknas, 2004:15). Pada penelitian ini aspek yang akan dibahas adalah aspek kelayakan isi buku teks bahasa Indonesia kelas X SMA edisi 2016.

Aspek kelayakan isi. Aspek ini menilai bahan pembelajaran yang disajikan di dalam buku pelajaran. Kriteria materi harus spesifik, jelas, akurat, dan mutakhir dari aspek penerbitan. Informasi yang disajikan tidak mengandung makna yang bias. Kosakata, struktur kalimat, panjang paragraf, dan tingkat kemenarikan sesuai dengan minat dan kognitif siswa. Kutipan pantun, cerpen, puisi, atau wacana yang diambil dari sumber otentik lain diberikan sumber rujukannya. Illustrasi harus sesuai dengan teks. Demikian pula peta, tabel, serta grafik harus sesuai dengan teks, harus akurat, dan sederhana. Sementara itu, perincian materi harus sesuai kurikulum. Perincian materi juga harus memerhatikan keseimbangan penyebaran materi di tiap subbabnya, baik yang berkenaan dengan pengembangan makna dan pemahaman, pemecahan masalah, pengembangan proses, latihan dan praktik, tes keterampilan maupun pemahaman.

Berdasarkan hasil wawancara, observasi, dan dokumentasi buku teks bahasa Indonesia kelas X SMA edisi revisi 2016 ini sudah layak. Hal ini diperkuat dengan hasil analisis kelayakan isinya berdasarkan instrument BSNP yang telah dimodifikasi. Berikut pemaparannya. Jika dilihat dari skor rata-rata hasil analisis buku teks, buku teks bahasa Indonesia kelas X SMA edisi revisi 2016 ini masuk pada kategori layak dengan skor 8,4, dengan skor maksimal 10. 
Tabel 1. Hasil Analisis Seluruh Bab

\begin{tabular}{|c|c|c|c|}
\hline NO. & BAB & SKOR & RATA-RATA \\
\hline 1. & BAB 1 TEKS LHO & 35,9 & 8,975 \\
\hline 2. & BAB II TEKS EKSPOSISI & 35,7 & 8,925 \\
\hline 3. & BAB III TEKS ANEKDOT & 37,1 & 9,275 \\
\hline 4. & BAB IV CERITA RAKYAT & 35,1 & 8,775 \\
\hline 5. & BAB V TEKS NEGOSIASI & 32,8 & 8,2 \\
\hline 6. & BAB VI DEBAT & 36,2 & 9,05 \\
\hline 7. & BAB VII BIOGRAFI & 29,5 & 7.375 \\
\hline 8. & BAB VIII PUISI & 32,9 & 6,58 \\
\hline & Jumlah & 275,2 & 67,155 \\
\hline \multicolumn{3}{|c|}{ Rata-rata keseluruhan } & 8,4 \\
\hline
\end{tabular}

Kemudian jika dijadikan grafik, maka akan terlihat hasilnya secara lebih eksplisit. Berikut grafik hasil analisis data. Dengan grafik, akan terlihat tinggi rendahnya nilai yang didapat dari hasil analisis per bab.

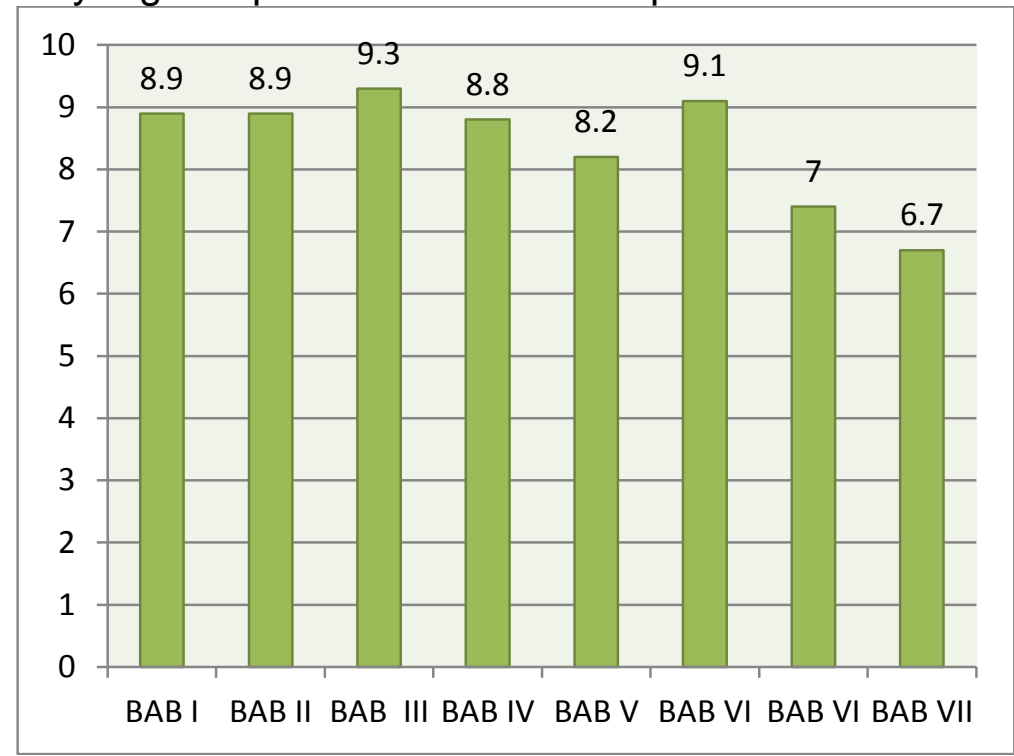

\section{Gambar 1. Hasil Analisis Buku Teks}

Hal-hal yang dinilai berkaitan dengan kelayakan isi buku teks antara lain:

1) Kelengkapan materi, yang terdiri dari wacana, pemahaman wacana, uraian materi, dan keluasan materi. Namun pada buku teks ini kelengkapan materinya masih kurang Materi yang terdapat pada setiap bab rata-rata hanya berupa wacana, dan uraian materi saja.
2) Kedalaman materi, yang terdiri kesesuaian wacana, teks, gambar, dan ilustrasi. Tingkat kesulitan dan kekompleksan wacana, teks, gambar, dan ilustrasi. Dan kualitas wacana, teks, gambar, dan ilustrasi. Untuk kedalaman materi di rasa masih kurang karena tidak ada penambahan wacana, teks, gambar, atau ilustrasi yang berfungsi sebagai pembanding. 
3) Pemilihan wacana, teks, gambar, dan ilustrasi yang terdiri dari uraian materi berdasarkan wacana, teks, gambar, dan ilustrasi. Pemilihan wacana, teks, gambar, dan ilustrasi sudah sesuai dengan tingkat pemahaman siswa.

4) Konsep dan teori sesuai sistematika keilmuan terdiri dari konsep dan teori yang disajikan untuk mencapai KD sesuai dengan definisi yang berlaku dalam bidang ilmu. Secara konsep dan teori buku ini sudah sesuai dengan tujuan standar isi dan KD yang diharapkan.

5) Pemilihan contoh terdiri dari uraian dan contoh melalui wacana, teks, gambar, dan ilustrasi.

6) Perlatihan, penugasan, dan penilaian sesuai dengan penilaian autentik terdiri dari perlatihan, tugas, dan soal-soal yang diajukan dapat mengukur penguasaan pengetahuan dan keterampilan. Untuk penugasan adalah menuntut keaktifan siswa.

7) Kesesuaian dengan perkembangan ilmu terdiri dari materi yang disajikan melalui wacana, teks, gambar, dan ilustrasi up to date. Sajian materi, wacana, teks, dan gambar sudah up to date. Yakni halhal yang terjadi pada tahun 2016 an.

8) Kesesuaian

fitur/contoh/latihan/rujukan terdiri dari uraian fitur/contoh/perlatihan

mencerminkan peristiwa dan kejadian yang ada.

9) Pengembangan wawasan kebhinekaan yakni materi, perlatihan, atau contoh yang disajikan melalui wacana, teks, gambar, dan ilustrasi membuka wawasan siswa untuk lebih mengenal budaya dan seluk beluk Indonesia.

10) Pengembangangan wawasan kebangsaan dari integrasi bangsa terdiri dari materi, perlatihan, atau contoh yang disajikan melalui wacana, teks, gambar, dan ilustrasi melahirkan kesadaran berpikir siswa untuk bangga menggunakan bahasa Indonesia.

11) Tidak mengandung unsur SARA, HAKI, dan pornografi yakni materi, perlatihan, atau contoh yang disajikan melalui wacana, teks, gambar, dan ilustrasi tidak mengandung unsur SARA, HAKI, dan pornografi.

Meskipun buku teks bahasa Indonesia kelas $X$ SMA edisi revisi 2016 ini pada kategori layak namun masih ada beberapa aspek yang harus lebih diperhatikan, agar pada edisi revisi berikutnya kualitasnya semakin baik. Hal yang perlu diperhatikan pertama kali adalah kelengkapan materi. Karena materi merupakan komponen utama yang harus dipenuhi sesuai dengan standar isi (KI dan KD) yang telah di tetapkan. Pada buku teks bahasa Indonesia kelas X SMA edisi 2016 ini ada satu materi yang tidak ada yakni materi mengenai buku fiksi dan nonfiksi. Padahal materi buku fiksi dan nonfiksi jelas tercantum dalam kompetensi yang harus diajarkan menurut ketentuan kurikulum. Kemudian kelengkapan wacana juga masih kurang, karena hanya memenuhi dua dari empat indikator misalnya gambar, teks, ilustrasi dan percakapan. Lalu pada kedalaman materi untuk kuantitas wacananya juga masih kurang, karena tidak ada penambahanan jenis wacana, teks, gambar, dan ilustrasi pembanding, penjelas, analogi dan kebutuhan lain sesuai tuntutan materi. Sehingga sangat diperlukan tambahan materi untuk memperdalam pemahan siswa.

Selain

permasalahan kelengkapan materi dan kedalaman materi ada lagi permasalahan yakni pada butir pengembangan wawasan kebhinekaan dan pengembangan 
wawasan kebangsaan dari integrasi bangsa. Pada buku teks bahasa Indonesia kelas X SMA edisi revisi 2016 ini penyajian materinya sudah mencerminkan wawasan kebhinekaan dan pengembangan wawasan kebangsaan dari intergrasi bangsa namun masih perlu ditambah karena ada beberapa materi yang tidak ada.

Buku teks ini dianalisis menggunakan instrumen kelayakan buku teks dari BSNP (Badan Standar Nasional Pendidikan) yang sedikit dimodifikasi dengan pendekatan saintifik. Namun instrument yang digunakan hanyalah instrument kelayakan isi saja, karena penelitian ini berfokus pada kelayakan isi buku teks bahasa Indonesia kelas X SMA edisi revisi 2016. Analisis buku teks sangat penting untuk mengetahui kualitas buku, terutama buku yang dijadikan sebagai sumber belajar siswa karena menurut fungsinya buku tersebut dapat mempermudah siswa dalam belajar. Buku teks merupakan salah satu komponen pembelajaran yakni sebagai sumber belajar. Oleh karena itu kualitasnya juga harus sangat diperhatikan.

\section{SIMPULAN}

Berdasarkan analisis yang telah dilakukan, maka dapat disimpulkan bahwa buku teks bahasa Indonesia kelas X edisi revisi 2016 ini termasuk pada kategori layak. Hasil analisis tersebut berdasarkan wawancara, observasi, dokumentasi serta analisis menggunakan instrument kelayakan isi buku teks dari BSNP. Namun meski demikian masih ada beberapa hal yang harus diperbaiki yakni kelengkapan materi, kedalam materi, pengembangan wawasan kebhinekaan dan pengembangan wawasan kebangsaan dari integrasi bangsa. Jika hal-hal tersebut dapat diperbaiki tentu kualitas buku teks bahasa Indonesia kelas X SMA akan semakin baik pada edisi revisi berikutnya.

\section{DAFTAR PUSTAKA}

Depdiknas. (2004). Kualitas Buku Pelajaran. Departemen Pendidikan Nasional. Jakarta.

Firdaus, A, dkk. (2014). Analisis Kelayakan Isi Buku Teks Bahasa Indonesia Terbitan Erlangga Kelas VII SMP/MTS. Jurnal Kata (Bahasa, Sastra, dan Pembelajarannya)(online).http://jur nal.fkip.unila.ac.id/index.php/BIND 01/article/viewFile/6274/3869 (Diunduh pada 15 September 2017)

Hartono, B. (2016). Dasar-Dasar Kajian Buku Teks (Konsep Dasar,
Pemilihan, Pemanfaatan, Penilaian, dan Penulisan Materi Ajarnya). Semarang: Unnes Press.

Hendrawanto, Y. (2017). Kelayakan Buku Teks Bahasa Indonesia SMA/SMK: Analisis Kebahasaan, Isi, Penyajian, Kegrafikaan, dan Keterbacaan. Semarang: Pascasarjana Universitas Negeri Semarang.

Mohammadi, M. \& Abdi, H. (2014). Textbook Evaluation: A Case Study. Journal Procedia - Social and Behavioral Sciences (online). 
www.sciencedirect.com (Diunduh pada 18 April 2018)

Undang-Undang No. 20 Tahun 2003 tentang Sistem Pendidikan Nasional.

Wikman, T. \& Horsley, M. (2012). Down and Up: Textbook Research in Australia and Finland. Journal IARTEM (International Association for Research on Textbooks and Educational). Vol. 5. No. 1. http://biriwa.com/iartem/ejournal/v
olume5.1/papers/Paper4 Wikman Downandup IARTEM eJournal Vol5No1.pdf. (Diunduh pada 17 Juni 2018) 